\title{
PENGARUH JENIS IKAN DAN ZAT PENAMBAH TERHADAP ELASTISITAS SURIMI IKAN AIR TAWAR
}

\author{
Endang Sri Heruwati ${ }^{*}$, Jovita Tri Murtini $\left.{ }^{*}\right)$, Siti Rahayu ${ }^{7}$ ), dan \\ Memen Suherman ${ }^{\text {*4) }}$
}

\begin{abstract}
ABSTRAK
Dalam rangka pemanfaatan yang lebih optimal dari beberapa jenis ikan air tawar, telah dilakukan penelitian untuk mengetahui pengaruh jenis ikan dan zat penambah terhadap kualitas dan kuantitas surimi ikan air tawar.

Jenis ikan yang digunakan dalam penelitian ini adalah ikan tambakan (Helostoma temminski c.v.), tawes (Puntius gonionotus), dan nilem (Osteocbillus basselti c.v.). Adapun zat penambah yang digunakan adalah garam meja dengan kadar $1 \%$ dan $2 \%$, gula pasir dengan kadar $3 \%$ dan $5 \%$, serta sodium polifosfat dengan kadar $0,2 \% ; 0,4 \%$; dan $0,6 \%$. Kualitas surimi ditentukan menggunakan parameter kekuatan gel (kg.mm) yang merupakan hasil kali dari nilai kekerasan dan kekenyalan, sedangkan kuantitas adalah rendemen yang diperoleh dari masing-masing jenis ikan.

Hasil penelitian menunjukkan bahwa dari segi kualitas, ikan tambakan mempunyai elastisitas yang jauh lebih baik dibandingkan dengan ikan tawes dan nilem. Dari segi kuantitas, ikan tambakan juga memberikan rendemen yang terbesar. Garam sangat nyata berpengaruh terhadap elastisitas surimi dari ketiga jenis ikan, sedangkan gula hanya berpengaruh terhadap kadar air produk akhir. Polifosfat hampir tidak memberikan pengaruh kecuali bila berinteraksi dengan gula atau garam.
\end{abstract}

ABSTRACT: Effect of Fish Species and Food Additives on the Elasticity of Fresh Water Fish Surimi, by: Endang Sri Herwwat, Jovita Tri Murtini, Siti Rabayu, and Memen Suberman

To optimize the utilization of fresh water fish production, a research on the effect of fish species and food additives on the quantity and quality of the surimi product has been conducted.

Three species of fish were used, i.e. kissing gouramy (Helostoma temminoki), Java carp (Puntius gonionotus), and carp (Osteochillus hasselti), while the food additives used were table salt ( $1 \%$ and $2 \%$ ), cane sugar (3\% and $5 \%$ ), and sodium polyphosphate $(0,2 \% ; 0,4 \%$; and $0,6 \%)$. Quality of the surimi produced were measured as gel strength value (kg.mm) which is resulted by multiplying the breaking force value by deformity value. The surimi yielded by each fish species were also noted.

Result of the experiment revealed that kissing gouramy seemed to be the best among the three species used, in term of both quality and quantity. Addition of salt was significantly affect the elasticity of surimi, while sugar only affected the moisture content of the product. There was not any effect of sodium polyphosphate on the texture of surimi, except when it was in interaction with either salt or sugar.

KEYWORDS: Freshwater fishes, food additives, surimi

\#) Peneliti pada Balai Penelitian Perikanan Laut, Jakarta

\#\#) Teknisi Litkayasa pada Balai Penelitian Perikanan Laut, Jakarta 


\section{PENDAHULUAN}

Dalam produksi perikanan secara nasional tahun 1992, perikanan air tawar memberikan sumbangan sebesar 851.264 ton, atau sebesar $24,02 \%$ dari total produksi (Anon. 1994). Jumlah tersebut terdiri atas 300.896 ton hasil tangkapan di perairan umum dan 550.360 ton hasil budidaya di kolam, keramba, dan sawah. Peluang peningkatan produksi melalui usaha budidaya baik secara ekstensif maupun intensif masih tersedia, sehingga diperkirakan produksi perikanan air tawar masih akan meningkat dalam beberapa tahun mendatang.

Statistik perikanan juga menunjukkan bahwa sebagian besar $(68 \%)$ produksi perikanan air tawar masih dipasarkan dalam keadaan segar atau hidup, walaupun ada sebagian yang dipasarkan dalam bentuk beku (udang galah), asin kering (sepat), pindang (tambakan), asapan (lais), dll. Cara pemasaran yang demikian kurang menguntungkan bagi upaya peningkatan produksi karena ikan hidup tidak dapat terlalu lama disimpan dan harus segera dikonsumsi. Pemanfaatan ikan air tawar menjadi bentuk olahan diperkirakan dapat memecahkan permasalahan ini.

Pengolahan ikan air tawar menjadi bentuk yang berbeda dari aslinya seringkali juga diperlukan apabila ikan berukuran terlalu kecil atau terlalu besar sehingga tidak sesuai dengan estetika dan selera konsumen. Di samping itu, usaha diversifikasi olahan ikan air tawar menjadi bentuk-bentuk yang lebih mudah dan cepat disajikan seperti surimi akan sangat membantu masyarakat yang semakin maju dan efisien menggunakan waktu. Kriteria yang paling penting dalam menentukan mutu surimi adalah elastisitas, oleh karena itu pada pembuatan surimi dilakukan pencucian daging secara berulang-ulang dengan tujuan untuk meningkatkan kadar protein miofibrilar yang akan mengakibatkan peningkatan elastisitas produk.

Selain tingkat kesegarannya, jenis ikan sangat berpengaruh terhadap elastisitas surimi yang dihasilkan. Untuk ikan laut, jenis ikan yang mempunyai elastisitas tinggi (strong asbi) antara lain adalah cucut martil/cucut biru, gulamah, ekor kuning, cumi-cumi; yang elastisitasnya sedang (medium asbi) adalah cucut botol, kembung, tuna sirip biru/kuning, sotong; sedangkan yang tergolong mempunyai elastisitas rendah (weak ashi) adalah tenggiri, japuh, terubuk, dll. (Tanikawa, 1985). Adapun untuk ikan air tawar, tidak banyak informasi yang tersedia, kecuali ikan nila yang mempunyai elastisitas medium serta ikan jelawat dan nilem yang mempunyai elastisitas rendah (Shimizu, 1985). Zain (1985) juga telah melakukan penelitian ikan tilapia cincang berbumbu, namun tidak menyebutkan mengenai elastisitas produk yang dihasilkan.

Faktor-faktor lain yang berpengaruh terhadap elastisitas surimi pada waktu pengolahan yaitu suhu, $\mathrm{pH}$, kadar air, serta jenis dan jumlah zat penambah (garam, gula, polifosfat, mono sodium glutamat/m.s.g., pati/tepung, putih telur, dll). Cara pengolahan yang baik dapat menghilangkan lebih banyak 
protein yang larut dalam air, dengan demikian meningkatkan protein miofibrilar yang sangat menentukan tekstur produk. Perlakuan pencincangan dan penggilingan juga menentukan tekstur. Suhu sangat berpengaruh terhadap pembentukan gel, di samping itu suhu yang terlalu tinggi selama pengolahan akan menyebabkan kerusakan mutu ikan yang berakibat rendahnya asbi. pH juga berpengaruh terhadap tekstur produk. Untuk cumi-cumi, pH optimum untuk .pembentukan tekstur adalah sekitar 6,7 (Pan, et al., 1979). Kadar air berpengaruh terhadap kadar dan hidrasi protein miofibrilar, oleh karena itu berpengaruh pula terhadap tekstur produk. Garam sangat menentukan tekstur karena garam dapat melarutkan protein miofibrilar. Gula bersifat krioprotektif, yakni mencegah terjadinya denaturasi protein selama penyimpanan beku, sedangkan polifosfat mendorong efek krioprotektan gula (Lee, 1984). Pati berfungsi dalam memperbaiki elastisitas, m.s.g. meningkatkan flavor, sedangkan putih telur memperbaiki penampilan produk sehingga tampak mengkilat (Wheaton and Lawson, 1985).

Walaupun zat penambah berpengaruh terhadap elastisitas produk, pengaruh ini sangat tergantung pada kadar masing-masing zat penambah (Rodger et al, 1985). Kadar yang sangat tinggi justru dapat menurunkan cita rasa produk.

Penelitian ini dimaksudkan untuk melihat pengaruh jenis ikan dan zat penambah terhadap elastisitas surimi ikan air tawar.

\section{BAHAN DAN METODE}

Dalam penelitian ini digunakan tiga jenis ikan air tawar, yaitu ikan tambakan (Helestoma temminoki c.v.), tawes (Puntius gonionatus), dan nilem (Osteocbilus basselti c.v). Ukuran ikan berbeda-beda menurut jenis: ikan tambakan berukuran 15-20 ekor/kg, tawes 8-10 ekor/kg, sedangkan ikan nilem berukuran 12-15 ekor/kg. Adapun zat penambah yang digunakan adalah garam (garam meja) dengan kadar $1 \%$ dan $2 \%$, gula (gula halus) dengan kadar $3 \%$ dan $5 \%$, serta polifosfat (sodium polifosfat p.a.) dengan kadar $0,2 \% ; 0,4 \%$; dan $0,6 \%$. Pengolahan surimi dilakukan mengikuti bagan pada Gambar 1. Penentuan elastisitas surimi dilakukan menggunakan parameter kadar air (\%) dan kekuatan gel (kg.mm). Kekuatan gel (gel strength) adalah merupakan hasil kali dari kekenyalan ( $\mathrm{mm})$ dan kekerasan $(\mathrm{kg})$.

Pengukuran kadar air dilakukan dengan metode drying oven $\left(100^{\circ} \mathrm{C}, 24\right.$ jam); kekerasan dan kekenyalan dengan menggunakan teksturometer LFRA dengan plunger berpenampang bundar dengan diameter $5 \mathrm{~mm}$.

Sampel untuk pengukuran kadar air diambil dari blok surimi beku yang telah dilelehkan pada suhu $5^{\circ} \mathrm{C}$ selama 12 jam. Adapun untuk pengukuran kekerasan dan kekenyalan, surimi yang telah dilelehkan tersebut dimasukkan ke dalam pipa stainless steel berdiameter $3 \mathrm{~cm}$ sepanjang $5 \mathrm{~cm}$ kemudian dikukus pada suhu $90^{\circ} \mathrm{C}$ selama 40 menit. Surimi kukus tersebut kemudian 
disimpan pada suhu $5^{\circ} \mathrm{C}$ selama 24 jam sebelum dilakukan pengukuran dengan teksturometer.

Analisis statistik dilakukan menggunakan program analisis sidik ragam tiga jalur dalam rancangan acak lengkap.

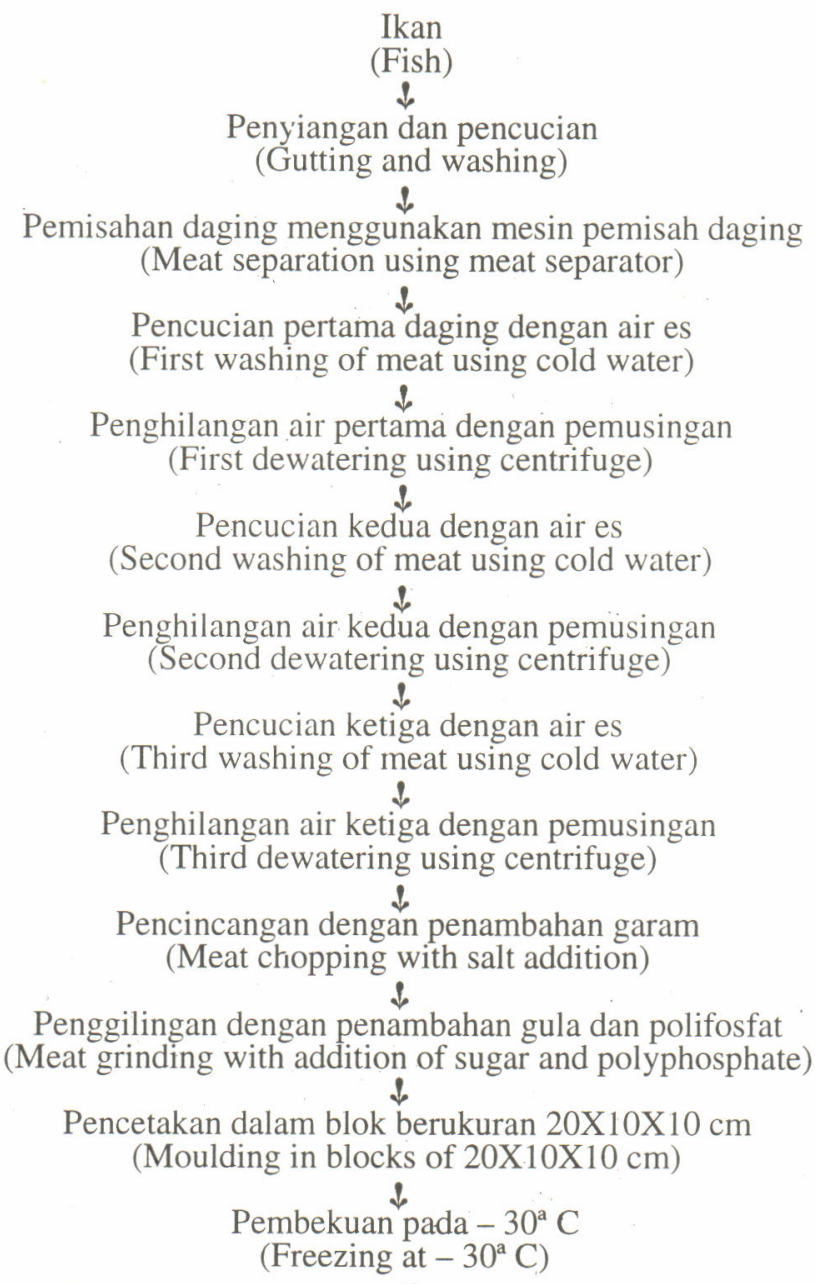

Gambar 1. Skema pengolahan surimi beku Figure 1. Processing scheme of frozen surimi

\section{Keterangan (Legend):}

Setiap pencucian dilakukan menggunakan rasio antara air es dan daging sebesar 2:1 diikuti pemusingan selama 30 menit (Washing was done 3 times using ratio of cold water and meat 2:1, followed by dewatering by centrifuge for 30 minutes) 


\section{HASIL DAN PEMBAHASAN}

\section{Mutu Bahan Baku}

Mutu bahan baku yang digunakan dalam percobaan ini masih sangat baik, karena ikan masih dalam keadaan hidup sewaktu tiba di laboratorium. Adapun komposisi kimia proksimat ikan adalah seperti tercantum pada Tabel 1 berikut.

Tabel 1. Komposisi kimia proksimat ikan air tawar *)

Table 1. Proximate composition of fresh water fis $\%$ )

\begin{tabular}{lcccc}
\hline \hline \multicolumn{1}{c}{$\begin{array}{c}\text { Komponen } \\
\text { Component }\end{array}$} & $\begin{array}{c}\text { Ikan tambalk } \\
\text { Kissing gouramy }\end{array}$ & $\begin{array}{c}\text { Ikan Nilem } \\
\text { Nile tilapia }\end{array}$ & $\begin{array}{c}\text { Ikan tawes } \\
\text { Puntius }\end{array}$ \\
\hline Air (Moisture) & $\%$ & 75,63 & 77,55 & 76,61 \\
Abu (Asb) & $\%$ & 4,22 & 1,37 & 1,31 \\
Protein & $\%$ & 24,86 & 18,45 & 17,83 \\
Lemak $($ Fat $)$ & $\%$ & 1,51 & 4,51 & 1,31 \\
\hline \hline
\end{tabular}

*) berat basah, rata-rata dari 2 ulangan (wet basis, mean of 2 replicates)

\section{Rendemen}

Hasil penelitian menunjukkan bahwa ikan tambakan, yang berukuran 15-20 ekor $/ \mathrm{kg}$, ternyata mempunyai rendemen (dalam bentuk daging cincang) yang tertinggi, yakni $25,7 \%$. Adapun ikan tawes yang berukuran lebih besar, 8-10 ekor/kg, rendemennya hanya mencapai $16,91 \%$, sedangkan ikan nilem (12-15 ekor $/ \mathrm{kg}$ ) mempunyai rendemen terkecil $(13,56 \%)$. Ikan tawes, selain rendemennya kecil, mempunyai kelemahan lain yakni dagingnya sulit dipisahkan karena adanya jaringan pengikat daging yang terlalu kuat.

\section{Pengaruh Jenis Ikan terhadap Elastisitas Surimi}

Nilai kekuatan gel dan kadar air surimi yang dibuat dari ikan tambakan, tawes, dan nilem dengan berbagai kadar garam, polifosfat, dan gula dapat dilihat pada Gambar 2 dan Gambar 3. Pada kedua gambar tersebut dapat dilihat bahwa surimi ikan tambakan ternyata mempunyai elastisitas (yang diukur dari kekuatan gel dan kadar air) yang jauh lebih tinggi dibandingkan dengan surimi ikan tawes dan ikan nilem. Surimi ikan tambakan mempunyai kekuatan gel antara 50-118 kg.mm dan kadar air antara 82,54-87,21\%. Surimi ikan tawes mempunyai kekuatan gel antara $13-45 \mathrm{~kg} \cdot \mathrm{mm}$ dan kadar air antara

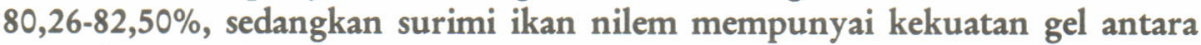
$11-46$ kg.mm dan kadar air antara $80,16-82,83 \%$. Hal ini sangat mungkin 
disebabkan oleh kadar protein ikan tambakan yang memang lebih tinggi dibandingkan dengan kadar protein dari kedua jenis ikan yang lain (Tabel 1).

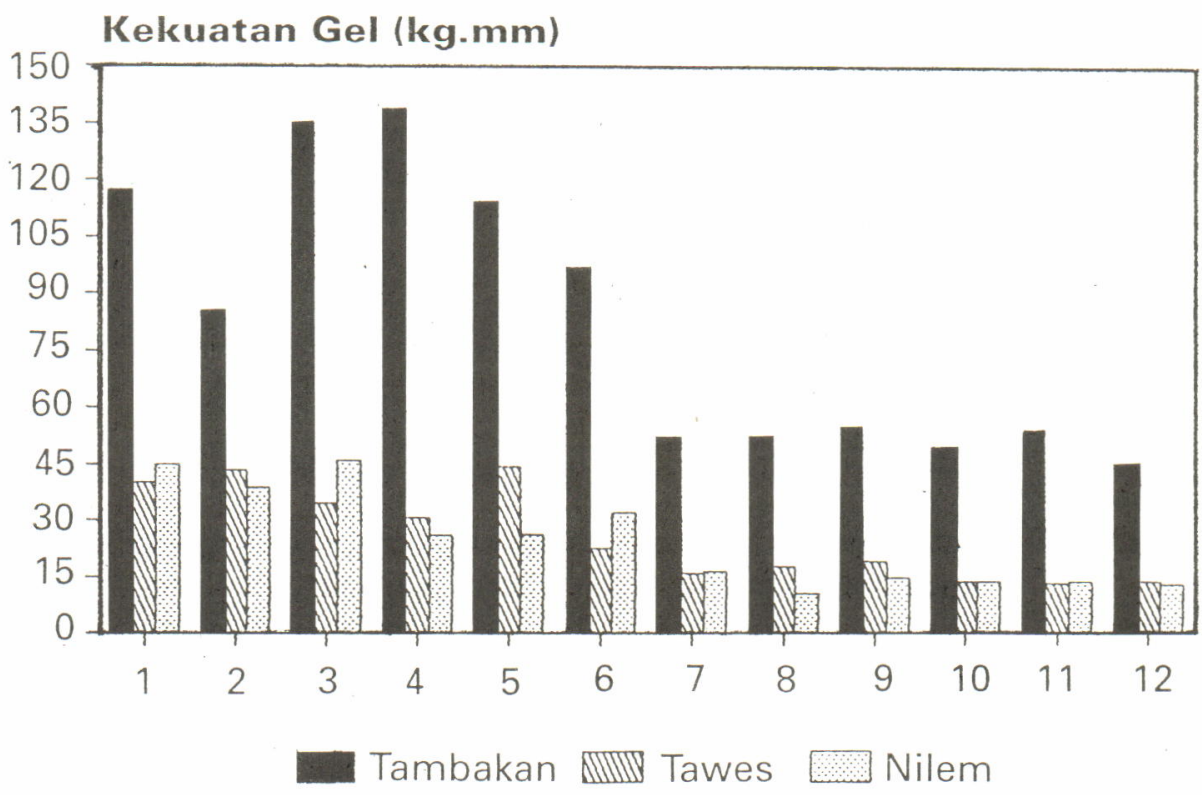

Gambar 2. Kekuatan gel surimi dari ikan tambakan, tawes, dan nilem dengan perlakuan bahan tambahan garam, polifosfat, dan gula

Figure 2. Gel strength of surimi of Kissing gouramy, Java carp and Carp using various concentrations of salt, polyphosphate, and sugar

Keterangan (legend):

1. Garam (salt) $1 \%$, polifosfat (polyphosphate) $0,2 \%$, gula(sugar) $3 \%$

2. Garam (salt) $1 \%$, polifosfat (polyphosphate) $0,2 \%$, gula(sugar) $5 \%$

3. Garam (salt) $1 \%$, polifosfat (polyphosphate) $0,4 \%$, gula(sugar) $3 \%$

4. Garam (salt) $1 \%$, polifosfat (polyphosphate) $0,4 \%$, gula(sugar) $5 \%$

5. Garam (salt) $1 \%$, polifosfat (polyphosphate) $0,6 \%$, gula(sugar) $3 \%$

6. Garam (salt) $1 \%$, polifosfat (polyphosphate) 0,6\%, gula(sugar) $5 \%$

7. Garam (salt) $2 \%$, polifosfat (polyphosphate) $0,2 \%$, gula(sugar) $3 \%$

8. Garam (salt) $2 \%$, polifosfat (polypbospbate) $0,2 \%$, gula(sugar) $5 \%$

9. Garam (salt) $2 \%$, polifosfat (polyphosphate) $0,4 \%$, gula/sugar) $3 \%$

10. Garam (salt) $2 \%$, polifosfat (polyphosphate) $0,4 \%$, gula/sugar) $5 \%$

11. Garam (salt) $2 \%$, polifosfat (polyphosphate) $0,6 \%$, gula(sugar) $3 \%$

12. Garam (salt) $2 \%$, polifosfat (polyphosphate) $0,6 \%$, gula(sugar) $5 \%$ 


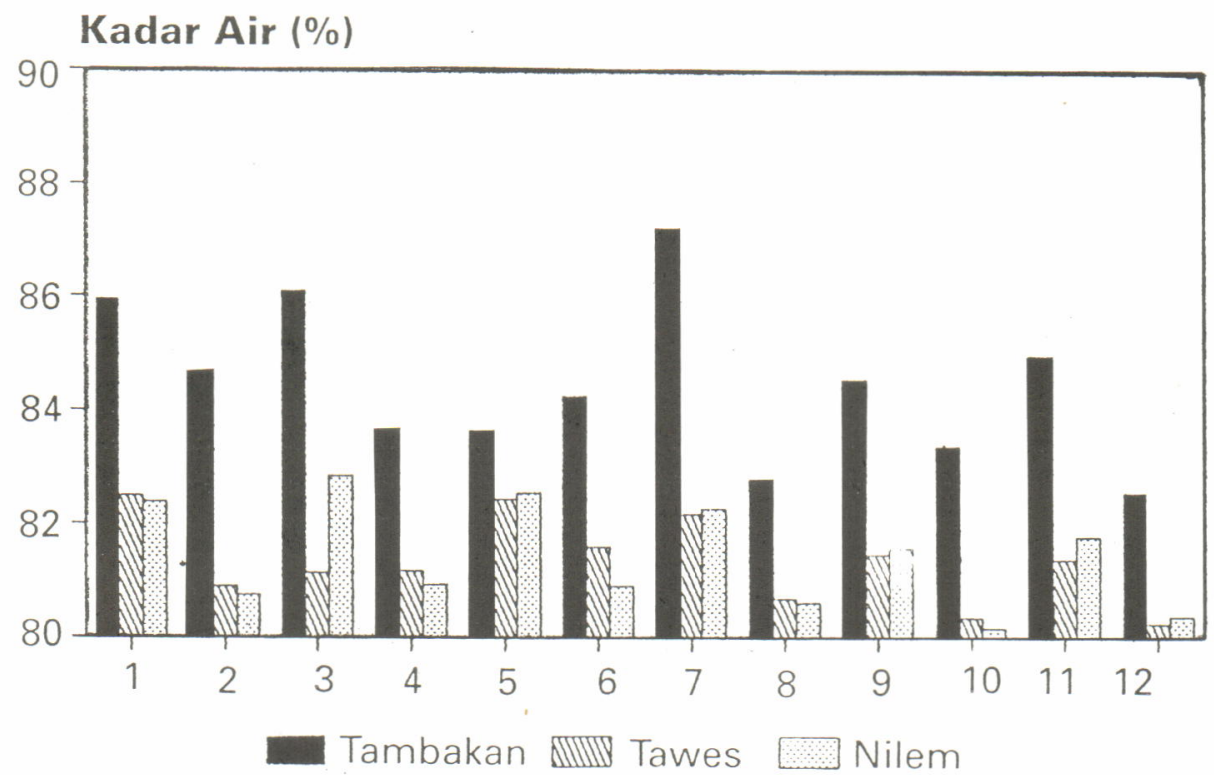

Gambar 3. Kadar air surimi ikan tambakan, tawes dan nilem dengan perlakuan bahan tambahan garam, polifosfat, dan gula

Figure 3. Moisture content of surimi of Kissing gouramy, Java carp and Carp, using various concentration of salt, polyphosphate, and sugar

\section{Keterangan (Logend)}

1. Garam (salt) $1 \%$, polifosfat (polyphosphate) $0,2 \%$, gula(sugar) $3 \%$

2. Garam (salt) $1 \%$, polifosfat (polyphosphate) $0,2 \%$, gula(sugar) $5 \%$

3. Garam (salt) $1 \%$, polifosfat (polyphosphate) $0,4 \%$, gula(sugar) $3 \%$

4. Garam (salt) $1 \%$, polifosfat (polyphosphate) $0,4 \%$, gula(sugar) $5 \%$

5. Garam (salt) $1 \%$, polifosfat (polyphosphate) $0,6 \%$, gula(sugar) $3 \%$

6. Garam (salt) $1 \%$, polifosfat (polyphosphate) $0,6 \%$, gula(sugar) $5 \%$

7. Garam (salt) $2 \%$, polifosfat (polyphosphate) $0,2 \%$, gula(sugar) $3 \%$

8. Garam (salt) $2 \%$, polifosfat (polyphosphate) $0,2 \%$, gula(sugar) $5 \%$

9. Garam (salt) $2 \%$, polifosfat (polyphosphate) $0,4 \%$, gula(sugar) $3 \%$

10. Garam (salt) $2 \%$, polifosfat (polyphosphate) $0,4 \%$, gula(sugar) $5 \%$

11. Garam (salt) $2 \%$, polifosfat (polyphosphate) $0,6 \%$, gula(sugar) $3 \%$

12. Garam (salt) $2 \%$, polifosfat (polyphosphate) $0,6 \%$, gula(sugar) $5 \%$

\section{Pengaruh Zat Penambah terhadap Elastisitas Surimi}

Pada surimi ikan tambakan, penambahan garam $1 \%$ ternyata memberikan nilai kekerasan yang sangat nyata lebih baik yang berarti juga memberikan kekuatan gel yang lebih baik dibandingkan dengan penambahan garam $2 \%$. Walaupun polifosfat pada kadar $0,2 \%, 0,4 \%$, atau $0,6 \%$ tidak memberikan pengaruh yang berbeda terhadap kekuatan gel, namun interaksi antara garam dan polifosfat ternyata memberikan pengaruh yang nyata. Penambahan $3 \%$ gula ternyata juga memberikan kadar air yang lebih tinggi pada produk dibandingkan dengan penambahan gula sebanyak $5 \%$. 
Pada ikan tawes, penambahan kadar garam 1\% dan gula 3\% ternyata memberikan nilai kekerasan, kekenyalan, dan kadar air yang lebih tinggi dibandingkan dengan penambahan garam $2 \%$ dan gula $5 \%$. Polifosfat pada kadar $0,2 \%$ juga ternyata memberikan nilai kekerasan yang paling baik dibandingkan kedua perlakuan yang lain.

Pada percobaan menggunakan ikan nilem, pengaruh penambahan garam, polifosfat, dan gula ternyata sama dengan hasil yang diperoleh pada ikan tambakan. Dengan demikian dapat dikatakan bahwa secara umum untuk ketiga jenis ikan yang dicoba, kadar garam $1 \%$, polifosfat $0,2 \%$, dan gula $3 \%$ adalah yang terbaik dalam hal elastisitas produk akhir.

Secara teoritis, garam memang berpengaruh terhadap elastisitas surimi karena dengan adanya garam, protein miofibrilar yakni aktin dan aktomiosin akan terlarut dan terdispersi secara homogen sehingga membentuk pasta yang lekat (viscous), yang bila kemudian mengalami perlakuan panas, akan membentuk gel yang elastis. Namun demikian, kadar garam yang terlalu tinggi juga akan berpengaruh buruk terhadap elastisitas karena garam yang berlebihan akan mengakibatkan terjadinya pengendapan (salting-out) protein. Hasil penelitian yang diperoleh memang agak berbeda dengan Okada (1985) yang menyatakan bahwa kadar garam minimum untuk membentuk elastisitas yang baik adalah $2 \%$. Perbedaan ini kemungkinan besar disebabkan oleh perbedaan jenis ikan dan kesegaran ikan yang digunakan. Lebih jauh, intensitas dan homogenitas penggilingan sangat berpengaruh terhadap tingkat elastisitas (Niwa, 1985). Dengan demikian faktor-faktor ini perlu dipertimbangkan dalam setiap pengambilan kesimpulan mengenai upaya perbaikan mutu surimi, dan tidak semata-mata hanya berdasarkan pengaruh zat penambah.

\section{KESIMPULAN DAN SARAN}

- Dari segi kualitas produk yang dihasilkan, tiga jenis ikan yang diteliti, yakni tambakan, tawes, dan nilem ternyata memberikan hasil yang cukup memuaskan. Meskipun demikian, ikan tambakan mempunyai elastisitas yang terbaik, dengan kekuatan gel 50-118 kg.mm dengan kadar air antara $82,54-87,21 \%$. Sedangkan ikan tawes dan nilem mempunyai elastisitas yang hampir sama rendah, yakni masing-masing $13-45 \mathrm{~kg} . \mathrm{mm}$ dan $11-46 \mathrm{~kg} . \mathrm{mm}$; dengan kadar air berturut-turut antara $80,26-82,50 \%$ dan $80,16-82,83 \%$.

- Dari segi kuantitas, ikan tambakan juga memberikan performansi yang lebih baik dibandingkan jenis ikan yang lain. Walaupun ukurannya lebih kecil (15-20 ekor $/ \mathrm{kg})$ ternyata rendemennya mencapai $25,7 \%$; sedangkan ikan tawes yang berukuran 8-10 ekor/kg hanya menghasilkan rendemen $16,41 \%$ dan ikan nilem berukuran $12-15$ ekor/ $\mathrm{kg}$ hanya $13,56 \%$.

- Untuk ketiga jenis ikan, penambahan garam $1 \%$ ternyata memberikan kekuatan gel surimi yang lebih baik daripada penambahan $2 \%$, sedangkan kadar gula 3\% memberikan kadar air produk yang lebih tinggi dibanding- 
kan dengan penambahan pada kadar 5\%. Perbedaan kadar polifosfat hampir tidak memberikan pengaruh terhadap kekuatan gel maupun kadar air, kecuali bila berinteraksi dengan penambahan gula atau garam.

Walaupun ketiga jenis ikan dapat menghasilkan surimi dengan elastisitas yang cukup baik, perlu dilakukan penghitungan kelayakan ekonomi, khususnya dikaitkan dengan pengusahaan pada skala industri, mengingat kecilnya rendemen yang diperoleh.

\section{DAFTAR PUSTAKA}

Lee, Chong M., 1984. Surimi Process Technology Food Techn. Nov

Niwa, Eiji, 1985. Functional Aspect of Surimi. R.E. Martin and R.L. Collette (Ed.). Proceeding of the International symposium on Engineered Seafood Including Surimi. Nat. Fish Institute. Washington D.C.

Okada, Minoru, 1985. Ingredients on Gel Texture. National Fisheries Institute, Washington.

Pan B.S., D.J.Lee, and L.P.Lin, 1980. Studies on a Minced Squid Product. Effect of raw material and ingredients on the texture of the product. Advances in Fish Science and Technology. Fishing News Books.

Rodger G. R.B.Weddle and P.Craig, 1980. Effect of Time, Temperature,Raw Material Type, Processing, and use of Cryoprotective Agents on mince quality. Advances in Fish Science and Techn. Fishing News Books.

Shimizu, Yutaka, 1985. Biochemical and functional properties of material fish. R.E.Martin and R.L.Collette (Ed.). Proceeding of the International Symposium on Engineered Seafood Including Surimi. Nat. Fish. Inst. Washington D.C.

Tanikawa E., 1985. Marine Products in Japan. Koseisha Koseikaku. Co. Ltd. Tokyo.

Wheaton F.W. and T.B.Lawson, 1985. Processing Aquatic Food Products. Willey Interscience Publishing, N.Y.

Zain, Asiah M., 1985. Spice Minced Fish from Tilapia. Advances in Fish Science and Techn. Fishing News Books. 